\title{
Realms of the Dead and the Living: George II's Allegorical Presence, Politics of Nonsense and Ignorance in Henry Fielding's The Author's Farce
}

\author{
Samia AL-Shayban \\ Associate Professor, Department of English Language and Literature, College of Arts, King \\ Saud University. ORCID ID: oooo-0003-3229-0834. Email: samia70o@hotmail.com
}

\begin{abstract}
Ideologically, Fielding's Author's Farce is read as an attack on Sir Robert Walpole and his corrupt government. Dramatically, it is perceived as a play with two separate plots, a factor that denies it any literary merits. This paper attempt to read Fielding's play as a disguised multifaceted attack against King George II of England who is accused of deliberately corrupting London' s literary scene to secure the Hanoverian hegemony. Fielding achieves his design through complex dramatization of the Realms of the dead and living. At the center of both realism stand George II who is metaphorically presented by the poor poet Luckless who resides in the land of the living and Nonsense the underworld goddess. The comparison between George Augustus who later became Prince of Wales and crowned as George II is based on detailed biographical and ideological similarities. The biographical and ideological affinities lead to the conclusion that King George II is the originator and protector of literary corruption. To strengthen the attack against the king, the court of Goddess Nonsense which appeared in Luckless' play that depicts the land of the dead is connected to George II's court through the prominent presence of opera and ignorance. Thus, Fielding's literary dramatization is used as a medium to expose the role of the King in devaluing the English literary scene and turns it into a circus that makes the public ignorant with no literary taste and resigns authors to poverty. The scene is the result a deliberate tactics designed to disempower authors and public as a way to spread the Hanoverian hegemony and silence criticism of the corrupt political system.
\end{abstract}

Keywords: Patriarchy, Margin, Center, George II, Power, Hobbes, Machiavelli.

\section{Introduction}

George Bernard Shaw writes that Fielding is "the greatest practicing dramatist, with the single exception of Shakespeare" (xvi). Robert Hume points out that modern critics rarely endorse Shaw's remark. He writes, "Few scholars have been much interested in Fielding's highly successful career as a dramatist" (Fielding 79). Hume's complaint that few critics concern themselves with studying Fielding's successful career as a playwright proved prophetic. When he marked Fielding's tercentenary through examining his critical history in 2010, he realized that the critics' attitude had not changed. According to Hume's reading, the criticism of Fielding's drama is "Elusive, Confusing, [and] Misappropriated" ("Fielding at 300" 224). He argues that the only way to improve the perception of Fielding's dramatic works is to show the appreciation his plays deserve ("Fielding at 300" 262). Writing in 1989, Albert Rivero denounces the critical trends that ignore Fielding's dramatic achievements and read him through his career as a novelist. He labels this approach as "teleological fallacy" and insists that it prevents critics from "examining [Fielding's

\footnotetext{
(C) AesthetixMS 2020. This Open Access article is published under a Creative Commons Attribution Non-Commercial 4.o International License (http://creativecommons.org/licenses/by-nc/4.o/), which permits non-commercial re-use, distribution, and reproduction in any medium, provided the original work is properly cited. For citation use the DOI. For commercial re-use, please contact editor@rupkatha.com.
} 
plays] in their own right, as dramatic entities worthy of serious critical scrutiny" (ix). In an attempt to endorse Shaw and Hume's approach that recognizes Fielding's position as a unique playwright in the history of English theatre, this paper proposes to re-read The Author's Farce's (1730/34) complex dramatization. ${ }^{\text {i }}$

Significantly, Fielding's The Author's Farce, which established his reputation as one of the most popular dramatists of his time, has been largely misinterpreted if not ignored (Rivero 31). The conventional criticism of play can be divided into two categories: dramatic and political. The dramatic readings judge the play to be composed of two distinct yet unrelated plots. From the political perspective, The Author's Farce is perceived as an undeniable attack against Walpole and his government. Indeed, Rivero can be considered one of Fielding's dramatic champions. He attempts to reveal Fielding's merits as a playwright through examining the dramatic structure of The Author's Farce. He argues that

The Author's Farce consists of two parts. The first, comprising acts one and two, deals with the romantic and monetary vicissitudes of the impecunious Harry Luckless. The second, act three, presents Luckless's gambit to rescue himself from his financial misfortunes, the puppet show enacting the "pleasure of the town." (35)

To Rivero, Fielding's plot falls into two parts. The first part is concerned with Luckless's life in the realm of the living. The second part is a play within a play (a puppet-show with real characters) which depicts a journey to the underworld. Lisa Freeman follows Rivero's reading and divides The Author's Farce into an inner and outer frame. She writes that "The outer frame for Fielding's allegorical puppet show features a hapless and poverty-stricken playwright named Luckless" (6o). To Freeman, the outer frame is the part which features the protagonist Luckless's real life with his "rounds of publishing concerns and playhouses to meet with booksellers and managers" (6o), while the inner frame is a "strange presentation of a life-size allegorical puppet show" in a dramatic form that depicts a journey to the realm of the dead (59). Thomas Keymer, who endorses Rivero's and Freeman's dramatic approach, indicates that there are two particular developments that

have dominated thinking about Fielding's output as a dramatist.... The first came with the passing in June 1737 of the Stage Licensing Act...The second key event was ... Fielding's reinvention of himself as a novelist in the 1740s. ...That seemed to efface the plays or identify them as a creative false start. ("Fielding's Career" 17)

Keymer refuses to read Fielding's plays through the Stage Licensing Act and his career as a novelist. Furthermore, he argues that The Author's Farce is a genuine expression of the literary scene of his time. To him the play is an "unmistakable avatar for [Fielding's] condition as a writer torn between high aesthetic ideals and pressing financial need" (Fielding's Career 24).

Apart from the literary reading, the political interpretation is a key factor in the critical analysis of The Author's Farce. Sheridan Baker argues that the play contains "threads of the antiWalpole satire that Fielding worked into his stage burlesque with increasing frequency" (221). Thomas Cleary also discusses the anti-Walpole approach embedded in The Author's Farce; he states that the play satirizes many aspects of Walpole's government, particularly the "electoral corruption" (32). In his turn, Alan Downie argues that in The Author's Farce Fielding makes use of complex innuendoes to convey the anti-Walpole message. Downie writes that the play is "susceptible of being constructed as political innuendo at the ministry" (37). 
Indeed the play is constructed as a "political innuendo" but not at Walpole. Thus, this paper proposes to challenge the dominant political-dramatic criticism and read the play as a masked attack against George II of England. The King is accused of deliberately corrupting the London literary scene as a measure to silence his opponents. The carefully masked attack is presented through his figurative dramatization as Luckless, the poet-king from the land of the living, and Nonsense, the goddess-queen of the underworld. To trace the King's figurative presence in The Author's Farce, the argument is structured in two parts. The first part links the protagonist, Luckless and George II. The poor poet turns out to be the Prince of Bantam and is later crowned as its king. These various identities are to be compared with George Augustus in his historical capacities as both Prince of Wales and King George II. The comparison focuses on their biographical details and their shift from the margin to the center of power. Furthermore, the analogy involves their ideological evolutions that accompanied the various stages of their transformations. The second part of the paper is concerned with the underworld experience. This part confirms the accusation levelled at King George II through Luckless. The technique implemented by Fielding is complex as it employs the literary motif of underworld journey as a source of revelation and sacred truth. Goddess Nonsense's character and her domain are compared to those of King George II. The connection of the two kingdoms, the underworld and the upper world, through the dead and living characters, is another way of unifying not only their literary practices as revealed through the plot but also associating them with those in King George II's historical London. To sustain the argument regarding London's literary scene dramatically and historically, new historicism approach is to be employed as a way of stressing the dynamic relationship between his text and its cultural and political milieu. The power game played by all concerned party in the play and is historical extension is to be explained through Thomas Hobbes and Michael Foucault's discourse on power. Hobbes' perception of power as a centered and unified concept is suitable to understand the mechanism of conventional power in dealing with its opponents. Michael Foucault's opposite belief in a decentralized power can explain the stand of the dramatic- historical key characters' unconventional power and their ideological transformation.

\section{A Puppet-King or a Decision Maker? George II between the Conventional Whig Historiography and the new Perspective of his Role}

Reading the play as an attack against George II might seem odd considering the King's historical reputation as a puppet-monarch whose policies were manipulated by his ministers, mistresses, and queen. In her review of Andrew Thompson's George II: King and Elector, published in Reviews in History, no. 1138, Clarissa Campbell Orr stresses that, in the history of the Hanoverians in general and George II in particular, there exists a gap that needs to be bridged. She endorses Thompson's argument about considering George II as a key political decision maker and argues that "the King was neither the puppet of the politicians nor subservient to petticoat government." Andrew Thompson complains about the limited information available about George II, a factor that makes it difficult to rescue him from the Whig's partisan propaganda (1-10). He also argues that we need to be aware of the "enormous condescension of Whig historiographical posterity" (3). The Whigs' history developed a picture that marginalized the king and placed themselves at the center. However, Thompson believes that the reality was different. He insists that "George was a King who still took an active role in governing" throughout his long reign (2). Such a historical reading of the King's role is important to the critical context of our argument. There are 
two reasons to justify its importance: first, the fact that George II is an under-researched monarch explains the conventional criticism of pointing to Walpole rather than George Augustus as the target of attack in The Author's Farce; second, the revised view of George II, from a dependent to an assertive and engaging ruler, means that the King can stand accountable for the literary corruption that marked his reign.

The masked and complex dramatic attack levelled at George II in The Author's Farce is to be understood by considering the turbulent political scene that dominated Fielding's era. This political turbulence was the result of the succession crisis and, by extension, the Jacobites' desire to restore the Catholic Stuarts to the English throne. It is essential, however, to stress that this paper is not directly concerned with the political conflict of the era, but rather with its manifestation in the literary scene of Fielding's London. The fact that King George II was the second Hanoverian monarch to ascend to the English throne did not make his position less precarious. It is true that George II's period was largely peaceful and without a direct military threat when The Author's Farce was staged. However, the cold war between George II and his government on one side and the Jacobites on the other never stopped. This was manifested through the Whigs-Tories partisan conflict and the government's tight control on theatres and the press. Louis Kronenberger argues that the "age though one of prosperity and peace, was far from tranquil" (42). Charles Knight insists that at the accession of George II, "there was ... hope amongst the Jacobites that something might be done" to restore the Stuarts (6o). In his article, "Jacobitism and the Historian," Karl Schweizer stresses the serious threat Jacobitism imposed during George II's reign. He draws attention to the fact that "Jacobitism was a divisive issue in British politics [where] the notion of an alternative monarch across the channel was viewed as legitimate by at least part of the political nation" (Jacobitism and the Historian). Schweizer explains that the Whig historiography downplayed the Jacobites' power and their influence. He further asserts that, to Fielding's contemporaries, Jacobitism "was no mere dynastic squabble but was viewed ... as a critical military, political and religious threat to the Hanoverian Establishment" ("Jacobitism and the Historian"). Schweizer insists that the contemporary response to the Jacobites' claim was favorable rather than hostile, a perception that finds its way into the recent historical approach to George II's reign. Schweizer proposes that revision to the Whig historiography produces a "complex web of factors that interactively shaped contemporary response ... to the Stuart restoration" ("Jacobitism and the Historian").

Being aware of the strong impact of Jacobitism during George II's era is essential to understand the political rift between the political parties: the Whigs and the Tories. Historically, the Tory party was accused of opposing the Hanoverian succession and supporting the Stuarts' restoration. Horace Walpole writes, "In truth, all the sensible Tories I ever knew were either Jacobites or became Whigs; those that remained Tories remained fools" (148). Linda Colley argues that the Tory party "Sought its salvation in the Pretender (James III): up to 1745 the Tories were predominately Jacobite, party engaged in attempts to restore the Stuarts by a rising with foreign assistance" (25). In opposition to the Tories stood the Whigs, who offered unshakable support to the Hanoverian succession. Colley claims that the Whigs' perception is marked by two important elements: "their suspicion of a disaffected Toryism" and "their justified apprehension of a Jacobite invasion based on the military and diplomatic supremacy of France" (26). Understandably, they were apprehensive about the Jacobites' desire to regain the English throne and end the Hanoverian rule with help from the French. Significantly, when the Whigs achieved political supremacy over the Tories, this failed to diminish their political insecurities. 
Due to their political anxieties, the Whigs found themselves in the middle of complex and multifaceted battles with several sides. Justin Du Rivage explains that the Whigs faced the Jacobites, the Tories, and an army of writers whose attacks were designed to bring about their political end (27). What concerns us in this context is the writers and the role they played in this conflict. For better understanding of the situation, we need to follow Thompson and Orr's advice and overlook the Whigs' historiography, which tends to marginalize the Crown when it comes to conflicts. Obviously, it was not in the Whigs' interest to show the Hanoverians as active players against sections of the English population and their choices. Such a picture had the potential to seriously damage the succession settlement, strengthening the Tories and Jacobites. Rivage explains that it was essential to understand that the Crown represented by George II and the Whigs' government under the leadership of Robert Walpole were complete partners. We should also keep in mind that it was only through this partnership that the Hanoverians could keep the English crown and the Whigs the government (Rivage 14-15). To achieve such goals, it was essential to control London's literary scene and the press. Jeremy Black stresses that Britain has a long history of acts aimed at regulating the press (2). He further argues that the given rationale behind controlling the press is "based on the theory that the freedom to print was hazardous to the community and dangerous to its ruler, a threat to faith, loyalty and morality" (Black 2; Clarke 6-11, 39-70). Michael Harris stresses that, after 1695, London witnessed an unprecedented increase in all types of publications (19). Such a growth in publications was accompanied by an increased interest in politics among the public, a factor that was perceived as an "unwelcome intrusion" by the politicians (Urstad 27). Unable to regulate the press, politicians from both parties, Whigs and Tories, used it as propaganda to promote their own views and discredit each other. Downie argues that, before the succession of George II, the Whigs in general and Robert Walpole in particular were "notoriously lax" about their political propaganda (111-123; Urstad 28). Historians agreed that the Whigs' relaxed attitude toward their opponents came to an end after George II's accession to the English throne (Urstad 29; Langford 28). After 1727 the Whigs who supported the Hanoverian succession became the target of unprecedented ruthless political attacks. Pointedly, theatre was remarkably hostile to Walpole and his policies. John Gay's The Beggar's Opera, performed in 1728 , ushered in a period of hostility toward the Whigs' policies. Langford writes that the play proved to be a highly effective political criticism of George II's rule, explaining that The Beggars Opera, “clearly depicted the court of George II as a kind of thieves' kitchen; the morality of the ruling class was put on a par with that of the London underworld" (21). We should also keep in mind that the immensely successful musical title bears the name of the genre most favored by George II. Gay's play did not go down well with the Whigs' authority and he was therefore prevented from staging its sequel Polly in 1729 (Winton 132-33). The play waited fifty years to be allowed a performance in London theatres in 1777 (O'Shaughnessy 22526). Prohibiting material deemed threatening to the authorities from reaching the public was part of the Whigs' policy to protect the Hanoverian succession and remain in power. To the Whigs it was "important that certain works should be prevented from circulating freely" (Urstad 32). Besides obstructing the circulation of certain material that meant to undermine their power or policies, they attempted to "diffuse and render harmless, propaganda ... produced by the opposition" (Urstad 32). To ensure the effectiveness of their policies, the Whigs' Ministry "set to work to improve ... the influence [it] already had in the world of publishing" (Urstad 30). This influence can be perceived through the government's army of paid authors who promoted the Whigs' policies and attacked the opponents (Urstad 36). Thus one can see that the Whigs "organized a comprehensive system for providing, printing, and distributing propaganda 
material" (Urstad 38). Unfortunately, propaganda was not always a sufficient means of control. When their authority was disturbed, the Whigs resorted to prosecution in the courts of law as another option to deal with certain difficult cases of opposition (Urstad 32-5). Authors opposing the Whigs proved themselves tough and unrelenting opponents. To ensure that their propaganda remained unchallenged, the Whigs under the leadership of Robert Walpole passed the Licensing Act in 1737. According to clause III of the Act, all new plays and entertainments "were to be submitted to the Lord Chamberlain" (Thomas 97), and the submission of any work was to take place not through the playwright but through "Masters or Managers ... of Playhouse or ... company of actors therein" (Thomas 97). This clause gave all decision-making power and legal rights to the theatre managers and stripped authors of their artistic freedom, their rights of ownership, and consequently their influence. Clause IV gives the Lord Chamberlain "total and arbitrary power of censorship against which there was no appeal" (Thomas 97). The Lord Chamberlain can also "prohibit an entire or part of a work as he shall think fit" (Thomas 97). Such practice does not fit with the principles announced by the Whigs that championed the Glorious Revolution of 1689 (Zook 1-30). The entire idea of deposing the legitimate king, James II, and the refusal to restore his heir, Prince James Stuart, after Queen Anne's death was pushed by promoting the concept of preserving people's liberties and rights. Surprisingly, the Whigs and King George II used the same argument to justify restricting the English people's freedom of speech. Thomas explains that "George II and Walpole, took the view that such liberty was in danger of degenerating into political license" (93). Furthermore, they also suspected that "theater had been infiltrated by Jacobite supporters" (Thomas 94). It is interesting to note that critics tend to fall under the influence of the Whigs' historiography narrative, blame Walpole, and overlook the role of George II in passing such an act. We should keep in mind that the Lord Chamberlain was the most senior official in the royal household. Historically, the Lord Chamberlain is directly accountable to the sovereign and not the government. Furthermore, he works under the royal prerogatives. This means that he is following the direct orders of the sovereign. Since he executes the wish of the sovereign, he enjoys the power and immunity of his master (Handley 3-17, 86-87). A. V. Dicey proposes that the prerogatives, "appears to be ... as a matter of fact nothing else than the ... arbitrary authority which at any given time is legally left in the hands of the crown" (Carroll 246). This definition shows that through the Licensing Act, the Whigs, were willing to go back to absolute monarchal power if it could help them to remain in power. Needless to say, the Licensing Act created an oppressive literary environment that lasted for two hundred years. Fielding staged The Author's Farce (1730/34) before the Licensing Act. However, the Whigs' propaganda machine with all its various parts was in full control of the London Literary scene. Such an oppressive environment rendered it necessary for authors to resort to a complex allegorical form of expression (Urstad 3). Fielding was no exception as he followed the practice of the day to avoid the Whigs' censorship and secure the staging of his play.

\section{Royal Heirs and Kings: Biographical Comparison of Luckless and George Augustus}

To prove that Luckless is the figurative representative of George Augustus, this paper begins by examining their similar biographical details. Significantly, the details they share make their affinity far from being a dramatic coincidence. As adults, both Luckless and Prince George realize that they are royal heirs to their fathers' crowns, which eventually they inherit. Toward the end of the play, Luckless is greeted by his best friend Witmore in unusual style as he shouts, "Long live his Majesty of Bantam" (3.23). Annoyed by the new form of greetings, Luckless expresses his 
surprise, "What, in the Devil's Name, is the meaning of this?" (3.23). Bantomite, who is his royal tutor, explains

Give me leave to explain myself. I was your Tutor in your earliest Days, sent by your Father, his pre-sent Majesty Francis IV, King of Bantam to show you the world. (3.23)

Bantomite, makes it clear that Luckless is in fact the royal heir to his father, King Francis IV of Bantam. Such a revelation is almost fantastical for a man who has lived all his life in obscurity and poverty. Interestingly, Prince George of Hanover, who had no confusion regarding his royal blood, was in a position similar to that of Luckless. The prospect of the German prince of Hanover inheriting the English crown was no less fantastical. Like Luckless, "Prince George Augustus was nearing the age of maturity when it became evident that his ultimate destiny lay beyond the duchy of Hanover" (Kiste 9). After the Glorious Revolution of 1688, the Bill of Rights was passed by parliament, which renounced James II and

brought his elder daughter Mary and her husband William of Orange to the throne ... No Roman Catholic could ascend the throne of England .... The heir to the childless widower King William III was his sister-in-law, princess Anne. (Kiste 9)

Unfortunately, Queen Anne failed to produce an heir. To solve the problem of succession, the Act of Settlement, which appointed the Protestant princess Sophie, the Electress of Hanover (James I of England's granddaughter), and her descendants as heirs to the English crown, was passed in 1701. Prince George was third in succession to the English throne after his grandmother and father George I (Kiste 9-10; Thompson 26-27).

The fact that Prince George became heir to the English throne caused him to be uprooted, leaving his country (the German State of Hanover) to live in London. Luckless is also uprooted from his kingdom of Bantam to live in London. His tutor explains that the king, his father, desired him to see the world; for that purpose they visit London. The tutor recalls the event:

We arriv'd at London, when one Day among other Frolics our ship's crew shooting the Bridge, the Boat over-set, and of all our Company, I and your Royal Self were only sav'd by swimming to Billingsgate. ... I lost for some time my Senses, and you, as I fear'd forever. (3.23)

Indeed, the tutor lost his royal charge and all attempts to find him failed. In his turn, Luckless clarifies the circumstances of his missing years. He explains that

I was taken half-dead by a Waterman, and convey'd Me to his Wife, who sold Oisters, by whose Assistance I recover'd-But the Waters of the Thames, like those Of Lethe, had caus'd an entire Oblivion of my former Fortune. (3.23)

Luckless's memory loss causes him to be disconnected from his royal roots and live as a commoner in London. On 31 August 1714, Prince George Augustus and his father, who became King George I of England, left their country behind and arrived in London on 18 September (Kiste 36; Thompson 39-40). Arguably, Hanover does not compare to the cosmopolitan London; yet George, as Prince of Wales and later as king, failed to warm to the country he was ruling. As George II, he paid long and frequent visits to Hanover, and only reluctantly returned to his "mean dull island" (Kiste 141). The frequent visits to his nation of origin and the reluctant returns to his adopted country suggest that George II felt dislocated in London and was in need of embracing his roots back in Hanover. 
This sense of physical alienation goes beyond the geographical location to embrace the emotional. It is significant to note that in spite of the fact that both Luckless and Prince George's families' circumstances are different, they are both estranged from their parents. Luckless grows up away from his father the king of Bantam and his mother. This is due to the fact that he was lost in the city of London. Bantomite explains that after

long fruitless Search for my Royal Master, I set Sail for Bantam, but was driven by the Winds on far distant coasts, and wander'd several Years, till at last I arriv'd once more at Bantam,-Guess how I was receiv'd-The King order'd me to be imprison'd for Life. (3.23)

Luckless is separated from Bantomite, his tutor, who fails to trace him in London. Furthermore, the help from Bantam is delayed as, for several years, Bantomite's ship is lost at sea. To make matters worse for the missing prince, upon the return of Bantomite to his country, the king sentences him to life imprisonment as a punishment for the loss of his son and heir. Due to these various unlucky incidents, Luckless lives part of his childhood and his entire adult life away from his royal parents. It is interesting to note that there is no mention of Luckless's mother. This brings to mind George's mother, who had not been part of his life since childhood. In spite of the fact that Prince George was not a missing child like Luckless, several factors pushed the Prince to live away from his parents. From an early age the Prince saw little of his father, who "was away on military service much of the time" (Kiste 6). The divorce of his parents, and the life imprisonment of his mother, Sophie Dorothea, upon the exposure of her extra-marital affairs, meant that the eleven-year-old George was not allowed to see his mother. Kiste writes,

On 28 December 1694 the marriage was dissolved. As the guilty party princess Sophie ... spent her remaining years as a virtual prisoner at Ahlden ... Forbidden access to her children. (7)After the divorce and for the rest of his father's life, "mention of the mother ... would always remain a forbidden subject" (Kiste 7 ).

Apart from their parental alienation, both Luckless and Prince George manage to embrace a satisfying emotional experience with their future queens. It is significant to note that both men meet their future queens in disguise and not in their royal capacity. Luckless falls in love with Harriot, the beautiful and kind daughter of his difficult landlady, Moneywood. Unhappy with the apparent familiarity between her only daughter and poor Luckless, she demands that their communications come to an end. Unfazed by his poverty, he confesses, "I love her as my Soul. Had I the world, I'd give it her all" (1.2). Unimpressed with Luckless's romantic confession, Moneywood tells him, "But as you happen to have nothing in the World, I desire you would have nothing to say to her" (1.2). As Harriot does not possess her mother's materialistic approach to life, she refuses to part with her poor love and promises, "I will take the first Opportunity of seeing you again" (1.3). Upon the crowning of Luckless as the King of Bantam, he tells his friends,

I am indebted to the golden Goddess, for having given me an Opportunity to aggrandize the mistress of my soul and set her on the Throne of Bantam. Come Madam, ...Once repeat your Acclamations, Long live Henry and Harriet, King and Queen of Bantam. (3.23)

Like Luckless, Prince George Augustus met his future queen, Princess Caroline Ansbach, while in disguise as Monsieur de Busch. The Prince "was travelling incognito as a young Hanoverian nobleman, planning to meet companions at Nuremburg. As they had not arrived, and as he found the city dull, he told officials, he had decided to come to Ansbach and see the court instead" (Kiste 15). The disguised Prince met the princess and "he declared that she had far exceeded all his expectations, and that he fell in love with her at first sight" (Kiste 15). The princess who was 
"favourably disposed" to the Prince's suit, accepted the marriage offer (Kiste 15). Like Luckless, who crowned Harriet as his queen of Bantam, Prince George, who succeeded his father George I on the English throne, crowned Princess Caroline as his queen consort on 11 June 1727.

\section{Agents of Power: Luckless, the Poet and George, Prince of Wales}

In addition to their mirrored biographical details, Luckless and Prince George share similar character traits. Luckless is a talented poet while Prince George's talent was manifested through his dynamic and engaging character. Furthermore, both are independent individuals who have revealed such quality through opposition to their different literary and political establishments. Talent and independence are marks of an unconventional source of power; to better understand the nature of Luckless and George's power and its mechanism, we need to employ the discourse on power as promoted by Thomas Hobbes (1588-1679) and Michel Foucault (1926-1984). Theories of power have a long and diverse history in which many prominent theorists participated. However, due to the nature of the argument, this paper takes an eclectic approach to the theoretical aspects. Hobbes is particularly helpful in understanding Luckless and George's unconventional power and the conventional authorities they oppose. Foucault enables us to perceive the more detailed picture and the evolution of forms of power displayed by the dramatic and historical characters. To the seventeenth-century philosopher, Hobbes, power "is centralized and focused on hegemony" (Sadan 34). In Leviathan he states that

The Greatest of human Powers, is that which is compounded of the Powers of most men, united by consent, in one person, natural or civil, that has the use of all their depending on his well. (Hobbes 62)

To Hobbes, man's power is essentially authoritarian and central. This power, which is "a single unit, [and] ordered according to a uniform principle," has a continuity of time and place that enables the agent to force his individual will upon others (Sadan 34). The non-traditional concept of power is rooted in a premise that perceives power as a decentralized concept. Foucault argues that "power is everywhere, not because it embraces everything, but because it comes from everywhere" (History of Sexuality 92). To Foucault, power is not an exclusive agent that can be controlled, distributed or taken away.

According to Foucault's concept, Luckless, the poor poet who lives on the social and literary margins, is a powerful agent. However, before we examine the source of Luckless's power, we need to stress the elements that makes him a Hobbesian powerless agent. Luckless is an unsuccessful dramatist who fails to stage any of his plays or indeed publish them. His jobless status turns him into a poor poet who cannot afford to pay his rent or feed himself. His frustrated landlady, Mrs. Moneywood, retaliates, "NEVER tell me, Mr. Luckless, of your Play, and your Play. I tell you, I must be paid ... Cou'd I have guess'd that I had a Poet in my House! Cou'd I have look'd for a Poet under lac'd Clothes!" ( 1. 1). To Mrs. Moneywood, poets are synonymous with poverty. As such, poets who "happen to have nothing in the world," and settle "Castles in the Air" are not welcome tenants (1. 1). Mrs. Moneywood makes it clear that she has no respect for his profession as a poet, which detaches him from reality and keeps him penniless. Luckless, who spends his time writing plays, is not only unable to pay his rent but also unable to pay for a meal. He confesses that, "I am afraid I shall scarce prevail on my Stomach to dine to-day" (1. 1). From the way Luckless is treated, it is apparent that he does not have the sovereign power that would push others to obey his well. Thus, according to the Hobbesian concept of power, he is powerless. 
To Foucault, on the other hand, the source of power is "inside" the individual, from which there is no "escaping" either for him or for those who are connected to this power relation (History of Sexuality 95). Accordingly, the jobless and penniless Luckless is not powerless. As a testimony of his power as a poet, Luckless is visited by two extremely influential figures of the London literary scene, Marplay Junior and Mr. Bookweight. The visit of Marplay Junior is motivated by the fact that Luckless has "a Tragedy for [his] House" (1. 6). Marplay Junior introduces himself

Mr. Luckless, I kiss your Hands-Sir, I am your most obedient humble Servant; you see, Mr. Luckless, what Power you have over me. I attend your commands, tho' several Persons of Quality have staid at Court for me above this Hour. (1. 6)

Apart from the exaggerated greetings, Marplay Junior knows that Luckless possesses an inner power, which is a talent to write plays. The plays he writes gives him a public voice that can speak to the audience. Thus, Luckless's public voice, embodied by his plays, is an essential commodity to Marplay's theatre. The skill to speak to the public through his plays and Marplay's need for this talent, make Luckless what Foucault labels as "power's articulation" (Power/Knowledge 95). He provides a clear representation that power cannot be controlled as it comes from within. Marplay Senior is also aware of the power of Luckless's creative writing. He explains his perspective regarding the art of writing:

The Art of Writing, Boy, is the Art of stealing old Plays, by changing the Name of the Play, and new Ones by changing the Name of the Author. (2.2)

To Marplay Senior, plays are only valuable to the extent he can recycle them: he steals old plays and changes the title, while for new plays the name of the author is supplanted. Such practice stresses Luckless's importance to the Marplays. It is essential to control and exploit his talent to write, as his plays provide a perpetual source of control over the audience; that is, over their taste and therefore their money. Foucault explains that at its roots power serves "as a general matrix ... that are sustained by all" (History of Sexuality 94). Luckless's power, generated through his talent/plays, is a matrix which the Marplays want to channel in their direction.

The desire to be part of Luckless's matrix of power is extended to Bookweight, who tells him, "I was told, Sir, that you had particular Business with me" (1. 7). This particular business is the publication of his play. Like the Marplays, Bookweight considers authors' works as an endless source of power. This is most obvious through his laborer-poets, whom he pays in return for their writings. He explains his method of selling books to one of his laborers, Scarecrow:

The Study of Book selling is as difficult as the Law, and there are as many Tricks in the one as the other. Sometimes we give a Foreign Name to our own Labours, and sometimes we put our Names to the Labours of others. (2. v)

Bookweight's philosophy of bookselling proves that he derives his power from exploiting his authors. Bookweight wants to share Luckless's power through publishing his plays or stealing them. This is another indication that Luckless's power is not "subjective," in the sense that it is not his exclusive property. It is a property shared by the author, the public, theatre mangers, and booksellers. Luckless himself is a product of the English Enlightenment which Foucault connects with "demoralization" and "decentralization" of power. In his critique of Foucault's concept of power and knowledge, S. Panneerselvam stresses that the Enlightenment's aim was similar to that of Foucault's: to "de-totalize history and society ... to de-center the subject" (15-16). The process of decentralizing power through knowledge reached its peak during Fielding's time. The 
unimpressed political establishment perceived the free speech of English theatres as a tool used to achieve two objectives - to disempower the system and empower the society (Gill 1-10). This motivated King George II and his minister Sir Robert Walpole to pass the Licensing Act of 1737 as a way of imposing a Hobbesian hegemony on the literary scene and by extension the English people.

From the Hobbesian perspective, George Augustus the Prince of Wales, like Luckless, is considered powerless. The title Prince of Wales was first conferred by Edward I on his son, in 1301. Since then it has become a tradition that "the eldest son of the sovereign is generally created Prince of Wales." Vernon Bogdanor explains the constitutionally powerless position of the Prince of Wales. The heir to the throne, "enjoy[s] ... the legal status of ordinary subjects," as such he "has no formal constitutional function" (51-52). This lack of constitutional executive power does not mean that the prince is powerless. Indeed, the prince's source of unconventional power is to be perceived through his dynamic and independent character. Sara Mills stresses Foucault's concept of power as "something which is performed" (35). She elaborates on Foucault's concept by explaining that "Power should be seen as a verb rather than a noun, something that does something, rather than some-thing which is or which can be held onto" (35). This concept of power as action is most befitting as a means to understand the George Augustus's dynamic nature, as a person who "made no pretense of thinking himself as anything but a man of action" (Kiste 46).

Indeed, the Prince was a man of action on military, political, and social levels. He was known for his bravery in the battlefield. Restless with his idleness, the Prince convinced his father to allow him to participate in the War of the Spanish succession. In 1708, during the battle of Oudenarde, he "led the life squadron of von Bulow's dragoon" (Thompson 32). During the battle, the Prince's horse was shot from under him. In spite of the danger, he refused to leave the battle. He told von Bulow that "he would uphold the family's honour ... [and] returned to the fray" (Thompson 32). As Prince of Wales, George displayed no less bravery. When acting as Guardian of the Realm during his father's absence in Hanover, he risked his life and helped to put out a fire that broke out at Spring Gardens. Furthermore, he remained unruffled after an attempt on his life was made at Drury Lane (Kiste 6o-61). On a political level the Prince's performance was no less impressive. He was known for his hard work and dedication. As Guardian of the Realm he "applied himself to be well with the King's Ministers and to understand the state of the nation" (Cowper 117). Walpole reported to Stanhope in Hanover that the Prince was "inquisitive about the Revenue, and calls daily for papers ... We are here chained to the oar, working like slaves" (Plumb 228-29). On a social level, the Prince of Wales was "kind and civil to everyone." His habit was to "dine in public and see company every evening." When he resided at Hampton Court he made it clear that Whigs and Tories were welcome to call on him. Kiste writes that they "were pleasantly surprised at the warmth of their reception." His social attention was directed not only to the politicians but to his local community as well, where he

Organized races for girls in the neighborhood, with gifts of clothing as prizes for the winners, and consolation prizes of ten shillings and a pair of scarlet stockings for the losers, not to mention free biscuits and wine for everybody at the end. (Kiste 58)

Prince George's character and accomplishments endeared him to the public (Kiste 46, 61). His popularity, which was reported to the King, is a testimony to his power. 


\section{Independent Spirits Opposition to the Hobbesian Establishments: Luckless and Prince George.}

The other identical manifestation of power Luckless and George share is independence. Their independence is apparent through the positioning of themselves as opposition agents to the dominating power in their respective contexts. In Prince George's position, the hegemonic power he faces is the political establishment presented by his father King George I and his government. Luckless, on the other hand, is facing a powerful literary consortium that includes theatre managers, booksellers and patrons. We should keep in mind, however, that Prince George and Luckless, with their unconventional power sources, are different from their opponents, whose concept and exercise of power is Hobbesian in nature. Sadan explains that Hobbes perceives power as a "position of will, as a supreme factor to which the wills of others are subjected" (34). If we consider the literary and political establishments that Luckless and George oppose, we can see clearly that these establishments are in positions of absolute power, which they employ to force others to submit to their will. By looking at the relationships between Luckless and the theatre managers, Marplay Senior and his son Marplay Junior, one notices that they are based on the sheer power of will. This is most obvious through the characters' perception and practice of power as something absolute and central. Marplay Junior informs his father Marplay Senior that he is not happy with the fact that he will inherit his position as a theatre manager, "Father, you wou'd leave me that art for a Legacy. Since I am afraid I am like to have no other from you" (2. 1). Marplay Junior's words regarding his dissatisfaction with his father's legacy is not the central issue in this context. What is key to our argument is the positioning of theatre management as a source of power that can be inherited. Such a form of power, where the son inherits from his father, is patriarchal in nature. To Hobbes, such practice is marked by "a continuity of time and place, from which the power stems" (Sadan 34). Unimpressed with his son's ignorance of the value of his legacy, Marplay Senior tells him

'Tis Buff, Child, 'tis Buff-True Corinthian Brass: And Heav'n be praised tho' I have giv'n thee no Gold, I have giv'n thee enough of that, which is the better Inheritance of the two. Gold thou might'it have spent, but this is a lasting Estate that will stick by thee all thy life. (2.1)

The metaphor which Marplay Senior employs to stress the value of his legacy is significant. Corinthian brass or bronze is a well-known metal in classical antiquity, particularly in the Roman world. It is a mixture of precious metals: gold, silver, and copper. The objects and artifacts made of this metal, such as statues, vases, warriors' helmets, and vessels were priceless. Another important fact about this metal is that its exact component, which makes it resist tarnishing, remains a mystery (Jacobson 6o). From Marplay's metaphor, one concludes that the theatre is not only a priceless form of art but also possesses lasting power like the Corinthian bronze. This metaphor also reveals that Marplay Senior is fully aware of the extreme power of theatre and consequently its value. To further appreciate such a metaphor, it would be helpful to understand the prevalent image of theatre managers during the eighteenth century. David Francis Taylor stresses that theatre managers during the Georgian era enjoyed a tremendous amount of power and wealth. He writes that the manager's conception as a "tyrannical brute who arbitrarily wields his or her considerable power over a defenseless public" was dominant. It was so to the extent that it became one of the "stock tropes of the period's theatrical commentaries" (70). It is noted that the power gained through their managerial position enabled them to amass financial wealth. Thus, with their social influence and economic advantages, theatre managers exercised decisive power over playwrights, actors and consequently the audience (73-76). The power of theatre 
managers in George II's era, cannot be considered a coincidence, especially when considering the existence of patent theatres regulated by the crown. One can concludes that the crown encourages the managers' power as a reward for their loyalty and the role they play in controlling the public taste and the of the dramatists.

It is of significant note that the Marplays try to force Luckless to obey their will and write according to their rules to ensure the staging of his play. Upon examining the play Luckless submits to be staged, Marplay Senior gives all kinds of trivial objections and demands changes. As a powerful figure, Luckless displays independence and refuses to accept Marplay Senior's requirements, as he tells him, "Sir, I cannot alter it" (2. 1). To that Marplay responds, "Nor we, cannot act it. It won't do' Sir, and so you need give yourself no further Trouble about it" (2. 1). Determined to oppose Marplay's dictates, Luckless refuses to alter his play; he bids him, "Fare you well, Sir: May another Play be coercive to your Passion" (2. 1). In spite of Luckless's desperate poverty, he refuses to submit to the theatre manager's hegemony. The dramatic hegemony Marplay is displaying goes further than refusing to stage one play. He explains to his son and heir, Marplay Junior, that Luckless's play, which he rejects, "may be a very good one, for ought I know; but I am resolv'd, Since the Town will not receive any of mine, they shall have none from any other. I will keep them to their old Diet" (2. 2). When his son inquires, "But suppose they won't feed on't," his father responds, “Then it shall be cramm'd down their Throats" (2. 2). It is obvious that Marplay acts as a despot who wants to monopolize the playwrights and by extension the audience. In spite of the comic façade, the situation is sinister at heart. The insistence on subjecting others (poets and audiences) to one's will, in spite of their resistance, is explained by Max Weber, who defines power as the possibility of an individual within a certain context to carry out his will despite resistance to it (Guzzini 100). To Weber this kind of power is illegitimate as it is a "threat to the freedom of the human spirit" (Sadan 35). Weber explains that authoritarian and hierarchic power is a confining element for the creative side of human beings (Sadan 35). Obviously, the talented Luckless is aware of such negative influence and as such he opposes Marplay Senior's authoritarian approach to his plays. Many critics have concluded that the powerful theatre managers, Marplays Senior and Junior, stand for the Cibbers-Colley and his son Theophilus (Battestin 107-108; Keymer "Fielding's Machiavellian Moment" 58-90). It is significant that Colley Cibber, who is present in The Author's Farce through Marplay Senior, had a strong relationship with the Crown represented by George II and the Whig ministry under the leadership of Walpole. The most obvious testimony for Cibber's connection with George II is his appointment as his poet laureate in 1730. This appointment was considered to be a political reward (Barker 157-58; Ashley 127). Cibber, who was an ardent Whig and supporter of the Hanoverian succession, was also the manager of Drury Lane Theatre, one of the most important and influential theatres in eighteenth-century Britain. Helene Koon acknowledges that as manager of Drury Lane, Cibber changed the "emphasis from the page to the stage" (x). What Koon tries to explain here is that Cibber was more interested in the theatrical sense rather than the literary merit of any play he staged at Drury Lane. This is exactly what his contemporary critics, playwrights, and poets opposed. They accused him of executing the political establishment agenda of damaging the theatre and corrupting the audience's taste (Koon 90; Bloom 243-58). To ensure the Hanoverian hegemony and empower the corrupt Whig government, the people were pushed to spend their time attending meaningless entertainments. Thus, the literary consortium in Fielding's play under the leadership of the Marplays echoes the situation that existed during George II's reign. 
The same oppressive application of power upon Luckless's literary creativity is exercised by Mr. Bookweight, the bookseller who rejects Luckless's play under various yet unconvincing pretexts. He refuses to consider it unless it is accepted by a theatre manager. When Luckless informs him that he will offer the play's copyright to the "Players" and not the booksellers, the annoyed Bookweight contradicts himself and produces another reason for refusing to publish it. He explains to Luckless

But a Play which will do on the Stage, will not always do for us; there are your Acting Plays, and your Reading Plays. (1.7)

Bookweight tries to explain the reason behind his decision. He argues that the acting play is "intirely Supported by the Merit of the Actor ... Now your Reading Play ... must have Wit and Meaning in't" (1.7). He differentiates between a play that will acted and one that will be read. The play that is written to be acted does not need to have merits as a good actor can add to its value. The same thing cannot be said about the reading play, which needs to be well written to be appreciated by the reading public. To him Luckless's play is of no value either for the stage or for the booksellers. He tells him, "Sir, I wou'd not give Fifty Shillings" (1.7). By devaluing the play which he has not read, Bookweight reveals a standard procedure that he follows which, unfortunately, does not take into account the real merit of the plays. Like Marplay Senior, Bookweight insists on subjecting others to his own terms. This is most obvious in the way he runs his bookselling and publishing business. In a style similar to that of the capitalists and colonizers, Bookweight exploits the poor writers, and steals their efforts to enrich himself while they remain poor. In his bookshop he employs various authors who translate and write poems, plays, and letters under his instruction. He tells Mr. Quibble, who writes him pamphlets, "I have had authors who have writ a pamphlet in the Morning, answer'd it in the Afternoon and answr'd that again at Night" (2.4). During the eighteenth century, author's such as Bookweight's were known as "hack writers." They were impoverished aspiring poets, playwrights, and journalists who resided in Grub Street. Edward "Ned" Ward who was a late seventeenth- and early eighteenth-century satirist asserts that the Grub Street hacks'

condition ... is much like that of a Strumpet, ... Why we betake ourselves to so Scandalous a Profession as Whoring or Pamphleteering, the same ... answer will serve us ... That the unhappy circumstances of a Narrow Fortune, hath forc'd us to do that for our Subsistence, which we are much asham'd of. (3; Troyer 3)

George II's regime encouraged such practices as it paid hack authors to promote its political agenda and attack its opponents (Clarke 58-60). Luckless refuses to be part of such an unethical practice and dismisses Bookweight from his house. He orders his servant, "Jack! Take this worthy Gentleman, and kick him down Stairs" (1. 7).

Besides theatre managers and booksellers, Luckless finds himself in opposition to another formidable component of the London literary scene: patrons. Concerned with Luckless's inability to stage or publish a play, his friend Witmore advises him,

get a patron, be Pimp to some worthless Man of Quality, write Panegyricks on him, flatter him with as many Virtues as he has Vices: Then perhaps you will engage his Lordship, his Lordship engages the Town on your Side, and then write till your Arms ake, Sense or Nonsense, it will all go down. (1. 5)

Unable to accept such a compromise to his artistic integrity, Luckless refuses Witmore's satirical advice to seek a patron. He insists that, "It is possible to thrive in the World by Justifiable Means" 
(1.5). Considering the patronage system in the eighteenth century, it is noteworthy that Witmore's explanation of the practice does not give the complete picture. Like London's literary scene, the patronage system is complex and multifaceted where the political, personal, and literary are connected. This factor renders the task of untangling such complexities in the limited space of this essay an unattainable ambition. Samuel Johnson defines the patron as "advocator, defender ... [and] vindicator" (90), and Dustin Griffin explains that eighteenth-century authors who stood "among enemies, rivals, critics or accusers" did need the aid of the powerful and wealthy patrons (21). Thus, an author with a patron received the protection he needed in London's highly aggressive literary environment. On the other hand the patron received the acknowledgement of his peers and society for his wit, cultured taste, and support of talented authors (Griffin 22-23). In his dedication to the Way of the World (1700), William Congreve addresses his patron, Earl Montague: "It is only by the countenance of your Lordship, and the Few so qualified ...that such who write with Care and Pains can hope to be distinguish'd" (x). The London Hobbesian literary consortium weakened authors and empowered the patrons. Griffin explains that

The patron is not only the guarantor of wit, reassuring the hesitating bookseller or book buyer, but is himself the source of it. It is only by acknowledging that authority, and in effect drawing on its power, that the client-writer may speak. (23)

Apparently Witmore and Luckless's negative perception of literary patronage is justified, since it marginalizes authors as the real source of talent, knowledge, and consequently power. They want authors to achieve literary success through their own talent and not through the reputation and financial standing of others. One notices that the theatre manager, the bookseller, and the patron try to control Luckless through their influence, money, and his poverty. Such behavior, which is designed to deny Luckless the freedom of his will, is a clear form of literary hegemony. Hobbes argues that freedom is achieved with the "absence of external impediments" (39; part 6). It is obvious that the power Luckless opposes is an external impediment which tries not only to control his freedom but most importantly to restrict his creativity and consequently power.

Like Luckless, Prince George faces an authoritarian Hobbesian political establishment that operates to deny him autonomy. Determined to have a voice, the Prince shows independence and opposes the political establishment represented by his father King George I and his government. The Hobbesian monarchal power George faces is "a single unit, ordered according to uniform principles, possessing a continuity of time and place, from which the power stems" (Sadan 34). Between 1716 and 1727, the Prince found himself treated by his father, the King, as a political and social outcast. Politically, Prince George was not given any active role. Kiste writes

The Prince of Wales was rigorously excluded from any governmental role in Britain and Hanover and also denied the military command for which he had proved himself evidently suited. (47-48)

When King George I left for Hanover for six months in July 1716, he refused to appoint his son Regent, to "act as head of the State in his absence" (Kiste 53). Instead he insisted on leaving his son "limited powers and the title Guardian and Lieutenant of the Realm" (Kiste 55). Socially, the prince was not in any better situation. His father the King declared him a social outcast, controlled his household affairs and his relationship with his own children. To George I, it was not enough that his son lived in his shadow, he also dismissed him from St. James's palace. To that effect, the Prince "received a note ... in the king's own hand" (Thompson 53); the King declared that the "children were to remain at court" (Thompson 53). When the Prince of Wales 
attempted to challenge his father's order at court, the "judgment was that royal grandchildren were the property of the crown so the king was entirely within his rights to determine how they should be educated" (Thompson 53). Furthermore, the King "indicated that anybody who attended his son ... at what was to become ... a rival court would not be welcomed by him" (Thompson 53). The King interfered in the management of his son's household and ordered him to dismiss the Duke of Argyll who "held the position of groom of the stole in George's household." The Prince, who was unhappy with such interference, was "left with little choice in the matter," and Argyll was dismissed (Thompson 53).

The Prince's opposition to his father's attempts to control him is made clear through the establishment of his own court and his attacks on the government. Upon his dismissal from St. James's he established courts of his own at Leicester House and Richmond Lodge. Leicester House soon became "pre-eminence as a center of London society" (Kiste 66). Courtiers and politicians "were tempted by the prospect of fine balls, assemblies and masquerades." The Summer Lodge at Richmond was no less popular as the Prince turned it into a "social and sporting center in summer" (Kiste 69). The social popularity of the Prince of Wales turned his courts into a "magnet for disaffected politicians." They became places "where Townshend and Walpole, prominent opposition Whigs, gathered with Tories" (Kiste 66). Lord Argyll, the Earl of Chesterfield, Lord Peterborough, and Sir Spencer Compton were a few of the prominent names that frequented the Prince of Wales's court and saw him as the opposition leader (Kiste 70-72). The prince and his supporters opposed some of the King's key policies such as separating the Crowns of HanoverEngland and increasing religious freedom in England (Thompson 48-50, 55). The opposition under the leadership of the Prince "increased in size and posed an ever-growing threat" to the King and his ministry (Kiste 71).

\section{Ideological Transformation: Luckless and George's Compromise and Adaptation}

Significantly, both Luckless and Prince George abandon their independence and refrain from opposing the Hobbesian establishments. The abandonment of their positions as opposition agents passes through two identical stages: compromise and adaptation. Before completely adopting the Hobbesian establishments' attitudes they used to oppose, they assume a compromising stand. Luckless and Prince George are pushed by the powers that be to act against their real interests. For years Luckless resists the literary establishment's dictates to abandon tragedies and write meaningless theatrical entertainments. Suddenly Luckless compromises his literary stand and writes what Marplay Senior and Bookweight want. When Luckless pays Bookweight a visit, the later insists that he will talk to him only if he has "a mind to compromise" and will write a work that can generate money (2. 6). To that Luckless responds that he has written "a puppet-show" (2. 6). He further confirms that the puppet-show "is to be play'd this Night in Drury-Lane playhouse" (2.6). Upon hearing such news, Bookweight invites Luckless to sign a book deal. He proposes, "If you will walk in, if I can make a Bargain with you I will" (2. 6). The fact that Luckless is acting against his real interest is clear through his awareness that he will remain excluded from the arena of power. He sacrifices his high literary ideals without gaining wealth or fame in return. When Bookweight asks him, "have [you] brought me any Money," Luckless responds, "Hast thou been in thy Trade so long, and talk of Money to a modern author? You might as well have talk'd Latin or Greek to him. I have brought you Paper, Sir" (2. 6). It is interesting to note that Luckless refers to his work as "papers." This indicates that his literary endeavor is mere worthless pages. What gives it value are theatre managers and booksellers. 
Becoming aware of such a latent power structure, he will not be different from any of the poor and hungry authors working under the direct dictates of Bookweight. Like Luckless, Prince George acts in a manner contrary to his own interest. He chooses to meet the political preference of the activators of power (in his case his father the King) rather than his own real concern. This is obvious through the contrition letter Prince George wrote to his father King George I asking for reconciliation. His pledge for peace with his father proved to be against his interest. To the Prince, the reconciliation "had been almost unconditional surrender" to the King, who was the winning party (Kiste 81). Lady Cowper writes, "They only made the Prince their cat's foot to compass their own ends, since he is thus betrayed into this most infamous way of making peace, without any real benefit for himself and the Kingdom" (135). As the head of the opposition, the Prince enjoyed popularity and power that posed an "ever-growing threat to the Ministry" (Kiste 71). The reconciliation deprived him of "the glory of Leicester House" and "of its attraction as center of opposition" (Kiste 81). The Prince gained nothing as his debts were unpaid and he remained excluded from government. Furthermore, the custody of his children remained with the King until his subsequent accession as George II. Amartya Sen demonstrates how people's perception is adaptable to the agenda of ideological hegemony. He writes that the hopeless rebellious agent,

learns to bear the burden so well that he or she overlook the burden itself. Discontent is replaced by acceptance,... suffering and anger by cheerful endurance. As people learn to adjust to the existing horrors by the sheer necessity of uneventful survival. (309)

Arguably, Luckless and George can be perceived as hopeless rebellious agents. Thus, they abandon their positions as opposition agents and accept the establishments' dictates.

It is interesting to note that both Luckless and Prince George move from their compromising positions to a complete adaptation of what they previously opposed. In both cases, the shift takes place when they are crowned as kings. When Luckless is hailed as King Henry I of Bantam, he immediately appoints in his domain all the figures from the London literary scene he passionately opposed. Addressing Monsieur Marplay and the Bookseller, "you shall super-intend my Theatres ... you my Bookseller" (3.24). Furthermore, he invites all the literary figures/genres who dominate London's corrupt literary scene. He appoints

\section{you, Sir, my Orator; You my Poet-Laureat ... you Don Tragedio, Sir Farcical, Signior Opera ... Mrs. Novel you shall be a Romance-Writer ... All proper Servants for the King of Bantam. (3.24)}

Fielding allows King Henry I/Luckless to singularly name all the appointed literary figures in his newly found court. By doing that, Fielding stresses Luckless's adaptation of London's literary scene. When Prince George inherited his father's crown and was proclaimed King George II of England, he appointed Sir Robert Walpole as his prime minister. Such a choice might seem logical considering Walpole's political and rhetorical abilities. However, upon the death of George I, Walpole's relationship with the heir to the throne was far from cordial. Walpole played an essential role in weakening the Prince's oppositional role to his father and government. As a result, the Prince "held it against him for some time to come" (Kiste 73). As a reward for abandoning his son's cause, King George I, "appointed [Walpole] First Lord of the Treasury ... and Chancellor of the Exchequer" (Kiste 77-78). Apparently George II, like the fictional Henry I, overlooked his previous opposition to the establishment, imitated his dead father, and appointed a political adversary as his prime minister. Walpole did not expect his appointment as he was 
aware of his role in manipulating the Prince to submit to his father without fulfilling any of the given promises. Kiste reports that "On 24 July Walpole was reappointed First Lord of The Treasury and Chancellor of the Exchequer, Townshend received the seal of the southern Department" (95).

By restoring Walpole and Townshend to power, George II was simply restoring his father's system, which he had spent his years as Prince of Wales opposing. In his turn, as King Henry I of Bantam, Luckless inherits Marplay Senior, Bookweight, and other literary figures/genres, which he has spent his years as a poor and unknown poet resisting. To consolidate their powers, King Henry I and King George II need to fortify their positions and weaken their detractors through using the effective resources of the establishment. Based on his previous experience as Prince of Wales, King George II was aware that Walpole and Townshend were part of the Crown resources. They were used effectively against him when he was Prince of Wales. The same thing can be said about King Henry I, who turns Marplay and Bookweight into essential figures in the Crown resources. He has firsthand experience of their roles in controlling London's literary scene. The multifaceted similarities between these dramatic and historical figures' biographical details, their Foucauldian unconventional power as talented and independent individuals, and their ideological transformations toward compromising attitudes and complete adaptation of the ideologies they used to oppose, are key elements in Fielding's attack against George II. He invites the audience to connect Luckless/King Henry I's final and deliberate act of surrendering his kingdom's literary scene to the corrupting agents with the actions of George II. The King, for the sake of his regime's hegemony, used his Crown resources, theatre managers, booksellers, and patrons to marginalize his opponents. This enabled him to corrupt and subsequently control London's literary sphere. Like the King of Bantam, George II institutionalized the corrupting process, a factor that made it difficult for those in opposition to win. Those who oppose the corruption lose, not because they are powerless, but because they are dependent like Luckless, the poor poet of the realm of the living. The Hobbesian powers in Fielding's London followed a deliberate tactic designed to disempower authors and prevent them from imparting the power of criticizing the corrupt system to the public. Denying the public this knowledge equates to denying them the power. A silent and ignorant public made it easier to spread the Hanoverian hegemony and silence criticism of the corrupt political system.

\section{George II and the Realm of the Dead}

Holding George II accountable for corrupting the London literary scene through his figurative representative Luckless, the poet in the dramatic realm of the living, is made more prominent through the presentation of the land of the dead. For that end Fielding uses three different techniques. The first technique is the journey to the underworld as a well-known and popular literary motif; the second, Goddess Nonsense's literary taste and her domain; the third, the connection between the realm of the dead and the living. The journey to the realm of the dead is a stereotypical literary motif in classical literature. In Homer's The Odyssey, Odysseus descends to the underworld to consult with the dead regarding his journey back to Ithaca. Stamatia Dova explains that "the objectives of Odysseus' trip to the underworld ... is to consult the soul of the seer Teiresias, who, even in death, has retained his ... powerful perception" (1). Orpheus takes a similar journey to retrieve his beloved wife, Eurydice, who died young. Elizabeth Henry explains that "in ancient times it was not doubted that Orpheus's katabasis was possible... Orpheus was believed to have power to restore others to life" (3). Virgil's Aeneas descends to the underworld to 
visit and consult his father's spirit about his voyage to the land of Latium and his future Roman Empire. The journey to the underworld gives Aeneas a resolve that has been missing from his actions. The doubts about his presence and future in the land of Latium is replaced by a clear vision of what is expected of him (Seider 28-65). All of these figures who descend to the underworld and consult with the dead return back to the land of the living to tell their story and experience with the ultimate truth. We should keep in mind that the information retrieved from the realm of the dead is considered by all as sacred and true. Thus, Fielding's dramatization of the underworld journey is designed to convince his audience to accept the retrieved political and literary message as a sacred truth. We should understand that Fielding's contemporaries were well aware of the classical mythological heroes who ascended to the underworld (Damrosch, Jr. 59; L. Orr 429-46). Radcliffe Edmonds argues that authors use the literary motif of visiting the land of the dead "to give authoritative and meaningful story to [their]... intended audience" (11). Keen to convince the audience to perceive his message as sacred truth, Fielding takes an objective stand. This is done through creating a double dimensional distance between himself and the realm of the dead. Luckless, the author of the play, and the play he creates are designed to distance Fielding from the underworld's message. Such dramatization is also a suitable ploy to mask his attack against George II while indirectly manipulating the audience to endorse as sacred truth his accusation against the King.

Having prepared the ground for the audience to accept his proposal, Fielding introduces Goddess Nonsense. The Goddess is the ruler of the underworld who poses as the metaphorical representation of George II. The fact that Nonsense is a goddess and not a god, does not weaken the argument regarding her metaphorical role as George II. In the mythology of ancient Egypt, Osiris the King of the Underworld "is said to be both male and female" (Antelme and Rossini 37). All living kings/pharaohs are Osiris in waiting. When dead, they are identified with him. It is through this "identification with Osiris, the deceased ... becomes both male and female" (Smith 212). According to the myth, dead souls seek Osiris Hall as he is not only the ruler of the underworld but also the judge of the dead. Fielding's audience were not only familiar with the journey to underworld and its sacred meaning but also with the ancient Egyptian mythology of Osiris, the king of the underworld (Gallien 387-401). Such awareness ensures that they can make the connection between King George II and Goddess Nonsense. The audience becomes aware of Goddess Nonsense's existence through a dead poet who wants to cross the river Styx to her Hall. The dead poet asks Charon, the ferryman of the underworld who carries the souls of the newly deceased across the river Styx, "Will thou be so kind as to show me the Way to the Court of Nonsense?" (3. 3 ). We should keep in mind that Nonsense is Fielding's dramatic invention. The definition of her name in the Cambridge Dictionary is "an idea, or behavior that is silly or stupid." Conventionally, goddesses have exotic names that invoke divinity, veneration and above all admiration. However, the unconventional name of Fielding's goddess does not seem to suggest a divine aura that commands respect. In such context, one can say that Fielding demystifies and humanizes his goddess. Fielding's demystification of Nonsense is contrasted by Charon's reverence. This can be seen through his surprise that a poor poet should seek Nonsense. Charon asks, "Ha, ha, the Court of Nonsense! Why, pray, Sir, what have you to do there? These Rags look more like the Dress of one of Apollo's People than of Non-sense's" (3. 3). In ancient classical antiquity, Apollo is a complex god with many functions and connections. Most notably, Apollo is the god of light and poetry, and the leader of the Muses who inspire art. He is also an agency who provides wise and truthful prophecy (Graf 5). It is obvious that Charon reveals an implicit contrast between Apollo's enlightened nature and Nonsense's ignorance. The apparent disconnection 
between Nonsense and poetry reminds the audience of George II, who was notorious for his aversion to all kinds of arts. He was quoted as saying, "I hate all Boets and Bainters" (Walpole 180). The connection between George II and Nonsense goes further to include their literary taste. Nonsense seems to be interested in Pantomime: upon receiving the various personified literary genres in her court, she honors Monsieur Pantomime with a personal greeting; when he fails to respond, she addresses her guests, "Alas, poor Gentleman! He is modest: you may speak, no Words offend, that have no Wit in them" (3. 7). Goddess Nonsense assures him that unintelligent conversation does not offend her. Nonsense's conversation with Monsieur Pantomime is of multifaceted meaning. English pantomime was performed as a musical comedy in which characters were silent or dumb and was enormously popular between 1720 and 1740 (O'Brien 490). Fielding was contemptuous of pantomime and described it as "irrational entertainment, a sign of the depravity of the audience's taste and the decline of the British stage" (O'Brien 490). By allowing Nonsense to honor Pantomime and address him, Fielding evokes George II, who was particularly interested in pantomime, in the minds of his audience. To accommodate the royal taste, Drury Lane Theatre staged Perseus and Andromeda; this play enjoyed "significant royal patronage, for George II commanded the performance on 20 and 30 November 1728" (Goff 134). Goddess Nonsense, with her apparent stupidity, low cultural taste, and unusual name, appears in sharp contrast to her supposed divine status. By creating this paradox, Fielding is in a better position to bring his goddess closer to King George II, who was not celebrated for his intellect. His father, George I, believed that his son was not an intelligent man and had readily fallen under the complete control of his clever and well-educated consort, Caroline Ansbach (Kiste 31). The King was known to be "Methodically minded, he lacked intellectual curiosity. Literature and art meant nothing to him" (Kiste 9). To further stress the connection between Nonsense and George II, Fielding allows his goddess to favor Opera. Goddess Nonsense, who is surrounded by the various literary genres contending for her favor, has chosen Signior Opera to be her husband. She addresses him, "pr'ythee take this Chaplet, and still wear it for my sake" (3.16). Luckless draws attention to the fact that "Signior Opera is created Arch-poet to the Goddess Nonsense" (3. 16). Annoyed by the several external influence to change her decision, she swears, "No more, by Styx I swear/ that Opera the crown shall wear" (3. 19). It is interesting to note that Chaplet, or the wreath in antiquity, is a symbol of achievement, status, and victory. It is also particularly associated with the Greek god Apollo. According to the myth, Apollo falls in love with a nymph, Daphne. When pursued by Apollo she asks the river god for help and he turns her into a laurel tree. From that day, Apollo wears a wreath of laurels on his head. Thus, Apollo's wreath symbolizes his love for Daphne and his status as god of light and art (Ovid 470-601). In antiquity, wreathes of laurels crown the heads of men of power, high status, and achievements. This particular image of Apollo in The Author's Farce is highly complex and significant. At times the god is used to highlight Nonsense's ignorance, thus marking the abyss that sets them apart. The fact that she bequeathed the laurel crown to Opera, mimics Apollo whose laurels are given to men of great artistic achievements. Thus, Apollo and Nonsense's latent/open comparison/contrast takes on a further dimension if we consider George II's preference for opera above anything else. George II and Queen Caroline were patrons and great fans of the opera that was performed in London under the direction of the German composer George Frederic Handel (Lang 222). Kiste asserts that "For several years the Prince and Princess of Wales had Patrons of Handel ... They were regularly seen at the opera and at river fetes where his music were performed" (50). As a mark of the King's taste for operatic music, he commissioned Handel to write the music for his coronation on 11 October 1727 (Range 129). Determined to please the uncultured and unintelligent King and his operatic taste, London's theatre proprietors concentrated "more on visual entertainments like... opera and 
dance ... which divert the sense more than the mind" (Kiste 50). Opera was so cherished by the King that his heir, Frederick, Prince of Wales, used it in their well-publicized conflict. The prince established an opera company, called The Opera of the Nobility. The company was meant to rival the Royal Academy of Music, which produced opera for its patron the King (Grout and Williams 712-28). The loud objections articulated in Nonsense's court regarding the appointment of Signior Opera as the Arch-poet, are echoed in Fielding's London. When Fielding was writing for the stage, opera was relentlessly attacked. Lang explains

The tradition and living force of the theatre in England did not permit the development of an alien form of the stage. The only concession English taste made was to music, an incidental ornament. The play-wrights of this highly developed and experienced theater held views concerning the drama that created an unbridgeable cleft between the spoken Theatre and opera ... In sum, they perceived in opera an abandonment of all they cherished, without adequate compensation by the music. (189)

Fielding's subtle and masked references to George II through Nonsense could not have been unrecognizable to a London audience.

To stress George II's role as a corrupting agent of the London literary scene, Fielding connects the realms of the dead and the living. The connection is effected through two different groups of characters, one group from each realm. The characters from the land of the living are Luckless, the author of the dramatic journey to the realm of the dead, the Constable, and Sir John the Magistrate. The characters from the realm of the dead are the poor poet and Bookweight. By considering Luckless to be from the realm of the living, one can say that he is a chorus-like figure from ancient Greek drama. The chorus in ancient Greek drama has several dramatic functions. Anastasia-Erasmia Peponi explains that "the chorus in Greek drama ... calls attention to its own corporal presence .... The chorus begs to be seen and heard" (34). In this particular context we will be concerned with its role as both a unifying and meaningful agent of control. Joshua Billings writes that the chorus plays a "formal role in guaranteeing the unities [of the] varying ... scenes" (136). Luckless is a complex version of the chorus as he plays the role of a unifying factor between the realms of dead and living. As the author, the director of his own play, and the commentator on its dramatic events, his role is one of triple dimensions. This means that, simultaneously, he exists in both realms and between them. Billings asserts that the chorus "observes the important actions of the characters" and gives "new force to the sentiments the dialogues of the protagonists have excited" (136-37). Like the chorus, Luckless constantly interferes in the underworld events, not through acting a specific character, but through explaining specific actions or introducing important characters. Luckless informs his audience, "Gentlemen, the next is Charon and a Poet; they are disputing about an Affair pretty common with Poets_-Going off without Paying" (3. 3). Charon is a mythological ghastly ferryman who, according to tradition, takes the dead souls across the legendary river Styx that separates the realm of the living from the dead and into the subterranean underworld (Edmonds 126-28). When the poor poet fails to pay Charon the needed fare for the crossing, he asks him, "Had you anything of Value buried with you?" (3. 3). To that the dead poet informs him that he has "Things of inestimable Value; six Folios of my own Works" (3. 3). At that stage, Luckless comments "Most Poets of this Age will have their Works buried with them" (3. 3). Luckless connects the dead poet's action of burying his books with a well-known practice in the land of the living. Through the chorus-like Luckless and the dead poet, Fielding underlines the unfavorable conditions of the literary scene in London and the complete disregard for poetry. This also reveals that Luckless, like the chorus in Greek drama, influences and directs 
the audience's interpretation of his play. He pushes them to perceive the two realms as one. By doing so, he reminds them of George II's metaphorical presence in the realm of the living and his historical role in corrupting the London literary scene and impoverishing talented poets.

The appearance of Sir John the Magistrate and the Constable, who belong to the realm of the living, in the middle of the dramatic land of the dead is yet another indicator that the two worlds are meant to be one. We should keep in mind that in eighteenth-century England the magistrate and the constable were part of the judicial system who were given the authority to enforce the law when necessary (Emsley 28-29). Both characters appear to arrest Luckless, the "Master of the Puppet-Show" (3.19). Upon asking for the reason for such a warrant, Luckless is informed by Sir John, "Shall you abuse Nonsense, when the whole Town supports it?" (3. 19) The Constable adds, "People of Quality are not to have their Diver-sion libell'd at this Rate" (3. 19). The fact that a character from the land of the living protects a character from the land of the dead is an indicator that the two realms are one. Consequently, the underworld's metaphorical characters are real in both a dramatic and historical sense. Thus, Nonsense is a dramatic persona that belongs to the land of the living and is consequently protected by its laws. This explains the Magistrate and his Constable's attempt to arrest Luckless for criticizing Nonsense. Through Luckless's dramatization and the reaction of the Magistrate, Fielding makes it clear that he opposes Nonsense's court and its literary taste. Once again Fielding is manipulating his audience to consider his historical stand against the literary corruption of his time. In harmony with the classical tradition and its response toward the representation of the underworld and its events, Fielding sanctifies Luckless's assessment of the literary scene. His perception is a sacred truth which the audience needs to take seriously. By extension Fielding solidifies his criticism of George II as the corrupter of London's literary sphere.

The two dead characters Fielding employs to connect the underworld with the land of the living are a poor poet and a bookseller. Upon the refusal of Charon to carry the spirit of the former, the poor poet complains,

What a wretched thing it is to be Poor? My body lay a Fortnight in the other World before it was Buried. And this Fellow has kept my Spirit a Month, sunning himself on the other side the River, because my Pockets were empty. (3.3)

Fielding makes it clear that he wants the audience to connect Luckless, as a poor poet, with the dead one. The poor poet remind us of Luckless himself, who is in constant dispute with his landlady over the payment of his rent. In this context the dead poor poet is not only a key character in connecting the realms of the dead and living but also in stressing Fielding's message regarding the impoverished poets in London. The audience are also invited to undertake the complex task and remember who is responsible for impoverishing writers in the land of the living and, by extension, George II's London. The other dead character who connects the realm of the dead with the living is the bookseller. While discussing with the poor poet the apparent infatuation of Goddess Nonsense with Signor Opera, he gives his own assessment of the situation.

That a Woman of so much Sense as the God-dess of Nonsense, should be taken thus at first Sight! I have serv'd Her faithfully these thirty Years as a Book-seller in the upper World, and never knew her guilty of one Folly before. (3. 5)

The bookseller of the underworld reminds the audience of Bookweight in the land of the living. He confesses that, as a bookseller, he faithfully served Nonsense when alive. This means that the literary consortium in the land of the living, and Bookweight, who is a member, are faithful 
servants to Nonsense and work under her direct instructions. Since George II is Nonsense, the audience are invited to perceive him in a similar light and align him with the corruption of London's literary scene.

\section{Conclusion}

Conventionally, Fielding's The Author's Farce, like the rest of his dramatic works, has attracted little critical attention. The nature of current analysis denies the play a suitable chance for an objective reading that attempts to decipher its meaning and expose Fielding's talent as a dramatist who not only dominated his age but most importantly influenced its theatre. The unpromising dramatic fate of The Author's Farce can be attributed to its complex and multifaceted nature. The dominant readings perceive the play as one work composed of two separate plots. Ideologically, the play is believed to be an attack on Sir Robert Walpole. These two elements are the key factors in the play's long history of critical misinterpretation. This paper challenges the dominant criticism and reads Fielding's play as an attack on George II and his role in corrupting London's literary scene, motivated by his agenda for political hegemony. This can be perceived by recognizing the play's single plot. Understandably, to deliver his message with impunity, Fielding represents George II through two different allegorical figures. In the realm of the living, the task of presenting the King under an allegorical mask is given to the poor poet Luckless. In the realm of the dead, Goddess Nonsense is the allegorical representative of George II. Fielding's play exists on two different levels, the living and the dead. The living level is Luckless's world while the land of the dead is the domain of Nonsense. However, both of Fielding's worlds are firmly connected not only with each other but most importantly with his historical era. The connection between the dramatic persona Luckless and the historical figure George is achieved through the alignment of their biographical details and ideological transformations. The affinities between them are so detailed that it cannot be considered a mere coincidence. Biographically, the two embrace their royal fortune late in life. They also suffer geographical and parental alienation. Interestingly, they both meet their future queens in disguise and not in their royal capacities. The biographical details encourage the audience to perceive them in a similar light and judge them accordingly. Their ideological journeys begin with an oppositional stand against the hegemonic powers in their particular contexts, only to move toward a compromising position and reach a complete adaptation of the practices they condemned. Thus, when Luckless is crowned as King of Bantam, he employs in his own kingdom the characters responsible for corrupting London's literary scene. By presenting this, Fielding invites the audience to connect such an act with George II, who on his own ascension to the throne, reemployed as his top aides his political enemies from his father's reign. The accusation of George II is stressed through Goddess Nonsense and her underworld kingdom. Like the King, Nonsense favors opera and pantomime but abhors poets, who are not welcome in her domain. The literary scene in the underworld echoes the literary circles in the realm of the living and in the historical London of George II. Thus, the message that King George II is responsible for corrupting the literary taste in his kingdom is not only clear but a sacred truth because, as in classical writing, it is confirmed through the journey to the underworld. 


\section{Endnotes}

i All quotes from Fielding's The Author's Farce are taken from 1743 edition. This edition is the revised version of the play that was premiered in 1730 . Since the argument is concerned with London's corrupt literary scene and those responsible, the 1743 version is more helpful. See The Author's Farce: With a Puppet Show; Called the Pleasure of the Town as Acted at the Theatre Royal in Drury-Lane, London, John Watt, 1750.

\section{References}

Antelme, Ruth Schumann, and Stéphane Rossini. (1998).Becoming Osiris: The Ancient Egyptian Death Experience. Translated by, John Graham. Vermont: Inner Tradition.

Ashley, L. R. (1965).Colley Cibber. (Twayne).

Baker, Sheridan. (1962). "Political Allusion in Fielding's Author's Farce, Mock Doctor and Tumble-Down Dick, PMLA, Vol. 77, No. 3Pp. 221-31.

Barker, R. H. (1939). Mr. Colley Cibber of Drury Lane. Columbia UP.

Battestin, Martin C. (1993). and Ruth R. Battestin. Henry Fielding: A Life. London: Routledge.

Billings, Joshua. (2013). "An Alien Body? Choral Autonomy Around 18oo." Choruses Ancient and Modern. Eds. Joshua Billings, Felix Budelmann, and Fiona Macintosh, Oxford UP, pp. 133-50.

Black, Jeremy. (2011). The English Press in the Eighteenth Century.( Taylor \& Francis.

Bloom Bissonette, Melissa. (2014), “The Right to Write; or, Colley Cibber and the Drury-Lane Monster.” The Lively Arts of the London Stage, 1675-1725, Ed. Kathryn Lowerre. Ashgate, pp. 243-58.

Bogdanor, Vernon. (1997). The Monarchy and Constitution.

Cambridge Dictionary. (Cambridge UP, 2019), dictionary.cambridge.org/dictionary/ english/nonsense.

Carroll, Alex. (2007). Constitutional and Administrative Law. Pearson Longman.

Clarke, Bob. (2004) From Grub Street to Fleet Street: An Illustrated History of English Newspapers to 1899. London: Ashgate.

Cleary, Thomas. (2006). Henry Fielding: A Political Writer. Wilfrid Laurier UP.

Colley, Linda. (1985). In Defiance of Oligarchy: The Tory Party 1714-1760. Cambridge: Cambridge UP.

Congreve, William. (2012). Dedication. The Way of the World, by Congreve, Ed. Philip Smith. Dover Publishing. pp. ix-xii.

Cowper, Mary, Countess. (1864). The Diary of Mary, Countess Cowper, 1714-20. London: John Murray.

Damrosch, Leopold, Jr. (1987). The Imaginative Works of Alexander Pope. Berkeley: University of California Press.

Dova, Stamatia.(2012). Greek Heroes in and out of Hades. Lexington Books.

Downie, Alan. (2009). A Political Biography of Henry Fielding. Routledge.

Edmonds, Radcliffe. (2004). Myths of the Underworld Journey: Plato, Aristophanes, and the "Orphic" Gold Tablets. Cambridge: Cambridge UP.

Emsley, Clive. (1992). “The English Magistracy, 1700-1850” IAHCCJ Bulletin, vol. 15, pp. 28-38.

Fielding, Henry. (1750). The Author's Farce; With a Puppet-Show Call'd The Pleasures of the Town. London: J. Watts.

Foucault, Michel. The History of Sexuality: An Introduction. Translated by Robert Hurley, Penguin, 1990.

---. Power/Knowledge: Selected Interviews and other Writings. Translated by Colin Gordon, Pantheon, 1980.

Freeman, Lisa. Character's Theatre: Genre and Identity on the Eighteenth Century English Stage. Pennsylvania UP, 2002.

Gallien, Claire, "Recycling the Orient in Eighteenth-Century British Literature: The Case of Busiris by Edward Young." Études anglaises, Vol. 63, No. 4, (2010), pp. 387-401.

Gill, Catie. Introduction. Theatre and Culture in Early Modern England, 1650-1737: From Leviathan to Licensing Act, Routledge, 2017.

Goff, Moira. The Incomparable Hester Santlow: A Dancer-Actress on the Georgian Stage. Ashgate, 2007. 
Graf, Fitz. Apollo: Gods and Heroes of the Ancient World. Routledge, 2009.

Griffin, Dustin. Literary Patronage in England, 1650-180o. Cambridge: Cambridge UP, 1996.

Grout, Donald, and Hermine Williams. (2003). A Short History of Opera. Columbia UP.

Guzzini, Stefano. (2017). "Max Weber's Power." Max Weber and International Relations, Ed. Richard Ned Lebow. Cambridge: Cambridge UP, pp. 97-118.

Handley, Miriam. (2004). The Lord Chamberlain Regrets: A History of British Theatre Censorship. British Library Publishing.

Harris, Michael. (1987). London Newspapers in the Age of Walpole: A Study of the Origin of Modern English Press. London: Associated UP.

Henry, Elisabeth. (1992). Orpheus with His Lute: Poetry and the Renewal of Life. Carbondale: Southern Illinois UP.

Hobbes, Thomas. (2005). Leviathan. Ed. Richard Tuck. Cambridge: Cambridge UP.

Hume, Robert. (1988). Fielding and the London Theater. Clarendon Press.

---, Robert D. (2010), “Fielding at 300: Confusing, Misappropriated, or (Perhaps) Obvious?” Modern Philology, Vol. 108, No. 2, pp. 224-62.

Jacobson, David. M. (2000) "Corinthian Bronze and the Gold of the Alchemists." Gold Bulletin, Vol. 33, No. 2, p.6o.

Johnson, Samuel. (1905). Lives of the English Poets. Vol. 3. Ed. G. B. Hills. Oxford: Clarendon Press.

Keymer, Thomas. (2007). "Fielding's Career." The Cambridge Companion to Henry Fielding, Ed. Claude Rawson, Cambridge UP. pp. 17-37.

---. (2008).“Fielding's Machiavellian Moment." Henry Fielding (1707-1754): Novelist, Playwright, Journalist, Magistrate, Ed. Claude Julien Rawson, Delaware UP. pp. 58-90.

Kiste, John Van der. (1997). George II and Queen Caroline. Sutton Publishing, 1997.

Knight, Charles. (2017) The History of England, 1714-1775, Vol. 6. The Forgotten Books.

Koon, Helene. (2015). Colley Cibber: A Biography. Kentucky UP.

Kronenberger, Louis. (2017). Kings and Desperate Men: Life in Eighteenth Century England. Routledge.

Lang, Paul Henry. (1996). George Frederic Handel. Dover Publications.

Langford, Paul. (2013). "The Rise of Robinocracy." Eighteenth-Century Britain: A Very Short Introduction, Oxford UP, pp. 13-31. Retrieved from www.veryshortintroductions.com/view/ 10.1093/actrade/9780192853998.001.0001/actrade-9780192853998-chapter-2.

Mills, Sara. (2003). Michel Foucault. London: Routledge.

O’Brien, John. (1998). "Harlequin Britain: Eighteenth Century Pantomime and the Cultural Location of Entertainments." Theatre Journal, Vol. 50, No. 4, pp 489-510.

Orr, Clarissa Campbell, (2012). "Review of George II: King and Elector." Reviews in History, No. 1138. Retrieved from www.history.ac.uk/reviews/review/1138.

Orr, Leah, (2016). "Dido and Aeneas in Eighteenth-Century England: Virgilian Imitation and National Identity.” Classical Receptions Journal, Vol. 8, No. 4, pp. 429-46. Retrieved from doi.org/10.1093/crj/clvo11.

O'Shaughnessy, Toni-Lynn. (1987-88), “A Single Capacity in The Beggar's Opera." Eighteenth Century Studies, Vol. 21, No. 2pp. 212-27.

Ovid, (2010). “Apollo and Daphne.” Metamorphoses, book 1, translated by Stanley Lombardo, Indianapolis, pp. 18-22.

Panneerselvam, S. (2000). “A Critique of Michel Foucault's Power and Knowledge." Indian Philosophical Quarterly, Vol. 27, Nos. 1-2, (2000), pp.15-28.

Peponi, Anastasia-Erasmia. (2013). “Theorizing the Chorus in Greece.” Choruses Ancient and Modern, edited by Joshua Billings, Felix Budelmann, and Fiona Macintosh. Oxford UP, 2013, pp. 15-34.

Plumb, J. H. (1956). Sir Robert Walpole: The Making of Statesman. Cresset.

Range, Matthias. (2012). Music and Ceremonial at British Coronations from James I to Elizabeth II. Cambridge UP. 
Rivage, Justin Du. (2012). Revolution against Empire: Taxes, Politics and the Origin of America. Yale UP. Rivero, Albert. J. (1989). Preface. The Plays of Henry Fielding: A Critical Study of His Dramatic Career, Virginia UP.

Sadan, Elisheva. (2005). Empowerment and Community Planning. E-Books.

Schweizer, Karl. (2013). "Jacobitism and the Historian: Some Neglected Sources on the Jacobite Insurrection of 1715 and 1745." Canadian Journal of History, Vol. 48, No. 3, pp. 441-57. Retrieved from www.questia.com/library/journal/1G1-36368840o/jacobitism-and-the-historian-some-neglectedsources. Accessed 29 Jul. 2018.

Seider, Aaron. (2013). Memory in Vergil's Aeneid: Casting the Past. Cambridge UP.

Sen, Amartya. (1997). Resources, Values and Development. Harvard UP.

Shaw, George Bernard. (1963). Complete Plays with Prefaces. Vol. 3. Dodd Mead.

Smith, Mark. (2017). Following Osiris: Perspectives on the Osirian Afterlife from Four Millennia. Oxford UP,

Taylor, David Francis. (2014). "Theater Managers and the Managing of Theater History." The Oxford Handbook of the Georgian Theater 1737-1832, Eds. Julia Swindells, and David Francis Taylor, Oxford UP, pp. $70-88$.

Thomas, David. (2014). “The 1737 Licensing Act and Its Impact.” The Oxford Handbook of the Georgian Theater 1737-1832, Eds. Julia Swindells, and David Francis Taylor, Oxford UP. pp. 90-106.

Thompson, Andrew C. (2011). George II: King and Elector. Yale UP.

Troyer, Howard. Ned Ward of Grub Street: A Study of Sub-Literary London in the Eighteenth Century. Routledge, 1968.

Urstad, Tone Sundt. (1999). Sir Robert Walpole's Poets: The Use of Literature as Pro-Government Propaganda, 1721-1742. Delaware UP.

Walpole, Horace. (1847). Memoires of the Reign of King George the Second, vol. 1. Henry Colburn Publisher.

Ward, Edward Ned (1698). "To the Reader" in A Trip to Jamaica. London. Retrieved from grubstreetproject.net/works/R905?display=text\&page $=3$.

Winton, Calhoun. (1993). John Gay and the London Theater. Kentucky UP.

Zook, Melinda. (1999). Radical Whigs and Conspiratorial Politics in Late Stuart England. Pennsylvania UP. 